\title{
China
}

Binghao Jia ${ }^{1,2,3}$, Xin Luo ${ }^{1}$, Ximing Cai ${ }^{3}$, Atul Jain ${ }^{4}$, Deborah N Huntzinger ${ }^{5}$, Zhenghui $\mathrm{Xie}^{1}$, Ning Zeng ${ }^{1,6}$, Jiafu Mao ${ }^{7}$, Xiaoying $\mathrm{Shi}^{7}$, Akihiko Ito ${ }^{8}$, Yaxing $\mathrm{Wei}^{7}$, Hanqin $\operatorname{Tian}^{9}$, Benjamin Poulter ${ }^{10}$, Dan Hayes ${ }^{11}$, Kevin Schaefer ${ }^{12}$

${ }^{1}$ State Key Laboratory of Numerical Modeling for Atmospheric Sciences and Geophysical Fluid Dynamics (LASG), Institute of Atmospheric Physics, Chinese Academy of Sciences, Beijing, China ${ }^{2}$ Key Lab of Guangdong for Utilization of Remote Sensing and Geographical Information System, Guangzhou Institute of Geography, Guangzhou, China

${ }^{3}$ Ven Te Chow Hydrosystems Laboratory, Department of Civil and Environmental Engineering, University of Illinois at Urbana-Champaign, Urbana, Illinois, USA

${ }^{4}$ Department of Atmospheric Sciences, University of Illinois at Urbana-Champaign, Urbana, Illinois, USA

${ }^{5}$ School of Earth Sciences and Environmental Sustainability and Department of Civil Engineering, Construction Management, and Environmental Engineering, Northern Arizona University, Flagstaff, Arizona, USA

${ }^{6}$ Department of Atmospheric and Oceanic Science, University of Maryland, College Park, Maryland, USA

${ }^{7}$ Environmental Sciences Division, Climate Change Science Institute, Oak Ridge National Laboratory, Oak Ridge, Tennessee, USA

${ }^{8}$ Center for Global Environmental Research, National Institute for Environmental Studies, Tsukuba, Japan

${ }^{9}$ International Center for Climate and Global Change Research and School of Forestry and Wildlife Sciences, Auburn University, Auburn, Alabama, USA

${ }^{10}$ NASA GSFC, Biospheric Sciences Laboratory, Greenbelt, MD, USA

${ }^{11}$ School of Forest Resources, University of Maine, Orno, Maine, USA

${ }^{12}$ National Snow and Ice Data Center, Cooperative Institute for Research in Environmental Sciences, University of Colorado at Boulder, Boulder, Colorado, USA

Correspondence to: Binghao Jia (bhjia@mail.iap.ac.cn)

\section{Models and data}

In this study, we used twelve terrestrial biosphere models (TBMs) that participated in the Multiscale Synthesis and Terrestrial Model Intercomparison Project (MsTMIP) (Huntzinger et al., 2013; Wei et al., 2014a, 2014b) to investigate the effects of climate change, land use and land cover change (LULCC), and rising $\mathrm{CO}_{2}$ concentration on the temporal changes in GPP. These models are 
Parameterization (CLM4VIC), Dynamic Land Ecosystem Model (DLEM), Global Terrestrial Ecosystem Carbon model (GTEC), Integrated Science Assessment Model (ISAM), Lund-PotsdamJena Dynamic Global Vegetation Model, Swiss Federal Research Institute WSL modification (LPJwsl), Organizing Carbon and Hydrology in Dynamic Ecosystems (ORCHIDEE-LSCE), Simple Biosphere version 3 by Jet Propulsion Laboratory (SiB3-JPL), SiB3 with Carnegie-Ames-Stanford Approach (SiBCASA), Terrestrial Ecosystem Model version 6 (TEM6), Vegetation Global Atmosphere and Soil version 2.1 (VEGAS2.1), and Vegetation Integrative SImulator for Trace gases

\section{Analysis methods}

The nonparametric Mann-Kendall method was used to determine the statistical significance of trends in Chinese and regional GPP (area-weighted), where the Sen median slope (Sen, 1968) was considered as the trend value in this paper. Trend analysis was based on annual values averaged from monthly values. The first step was to test for statistical significance of trends by computing the MannKendall statistic $S$. Each data value was compared with all subsequent data values as follows:

$S=\sum_{k=1}^{n-1} \sum_{j=k+1}^{n} \operatorname{sgn}\left(G P P_{j}-G P P_{k}\right)$,

$$
\operatorname{sgn}\left(G P P_{j}-G P P_{k}\right)=\left\{\begin{array}{c}
1, G P P_{j}>G P P_{k} \\
0, G P P_{j}=G P P_{k}, \\
-1, G P P_{j}<G P P_{k}
\end{array}\right.
$$

where $n$ is the length of the record for a given grid cell or region. The variance of $S$ (Eq. (3)) was then calculated to test for the presence of a statistically significant trend using the $Z$-value (Eq. (4)):

$$
\begin{array}{r}
\operatorname{var}(S)=\frac{1}{18}\left[n(n-1)(2 n+5)-\sum_{p}^{q}\right. \\
Z=\left\{\begin{array}{ll}
\frac{S-1}{\sqrt{\operatorname{var}(S)}}, S>0 \\
0, & S=0 \\
\frac{S+1}{\sqrt{\operatorname{var}(S)}}, & S<0
\end{array} .\right.
\end{array}
$$


$79 f_{i}=\frac{\sum_{t} \frac{A_{i} x_{i, t}\left|X_{t}\right|}{X_{t}}}{\sum_{t}\left|X_{t}\right|}$,

$80 \quad X_{t}=\sum_{i} A_{i} x_{i, t}$, in month $t$.

where $q$ is the number of tied groups and $t_{p}$ is the number of data values in the $p^{\text {th }}$ group. The statistic $Z$ was compared with a tolerable probability (the default significance level was set to 0.05 in this study). If a linear trend was statistically significant, then the change per unit time was estimated using a simple nonparametric procedure developed by Sen (1968):

$b_{\text {sen }}=\operatorname{Median}\left(\frac{G P P_{j}-G P P_{k}}{j-k}\right), j>k$.

If there were $n$ values of $G P P_{j}$ in the time series, as many as $n(n-1) / 2$ slope estimates could be obtained, and $b_{\text {sen }}$ was taken as their median.

Each region's relative contribution to the interannual variation (IAV) and seasonal cycle amplitude (SCA) of China's GPP was also calculated based on the method proposed by Ahlström et al. (2015) and Chen et al. (2017). The regional contribution $R_{j}(j=1,2, \ldots, 9)$ to the IAV of China's GPP was calculated using the following equations:

where $x_{i, t}$ is the GPP anomaly for region $i$ in year $t, A_{i}$ is the area of region $i$, and $X_{t}$ is the area-weighted total GPP anomaly in the whole of China in year $t$. By this definition, $f_{i}$ is the average relative areaweighted anomaly $A_{i} x_{i, t} X_{t}$ for region $i$, weighted by the absolute regional area-weighted anomaly $\left|X_{t}\right|$. $f_{i}$ ranges from -1 to 1 . Higher positive $f_{i}$ indicates that IAV in the region varies in phase with integral IAV and makes a larger contribution towards the IAV of China's GPP, whereas a smaller or negative $f_{i}$ represents the opposite. In the same way, the regional contribution to the seasonality of China's GPP was calculated using Eq. (6), in which $x_{i, t}$ is the monthly GPP departure from the annual mean (seasonal anomaly) for region $i$ in month $t$ and $X_{t}$ is the area-weighted total seasonal GPP anomaly for all China 
Table S1. MsTMIP Terrestrial Biosphere Models (TBMs) used in this study including SG1, SG2, and

$93 \quad$ SG3 simulations

\begin{tabular}{|c|c|c|c|c|c|}
\hline & \multirow{2}{*}{ Model } & \multicolumn{3}{|c|}{ Simulation } & \multirow{2}{*}{ References } \\
\hline & & SG1 & $\mathrm{SG} 2$ & SG3 & \\
\hline 1 & CLM4 & $\mathrm{O}$ & $\mathrm{O}$ & $\mathrm{O}$ & $\begin{array}{l}\text { Shi et al. (2011), Mao et al. } \\
\text { (2012) }\end{array}$ \\
\hline 2 & CLM4VIC & $\mathrm{O}$ & $\mathrm{O}$ & $\mathrm{O}$ & Lei et al. (2014) \\
\hline 3 & DLEM & $\mathrm{O}$ & $\mathrm{O}$ & $\mathrm{O}$ & Tian et al. $(2011,2012)$ \\
\hline 4 & GTEC & $\mathrm{O}$ & $\mathrm{O}$ & $\mathrm{O}$ & Ricciuto et al. (2011) \\
\hline 5 & ISAM & $\mathrm{O}$ & $\mathrm{O}$ & $\mathrm{O}$ & Jain et al. (2013) \\
\hline 6 & LPJ-wsl & $\mathrm{O}$ & $\mathrm{O}$ & $\mathrm{O}$ & Sitch et al. (2003) \\
\hline 7 & ORCHIDEE-LSCE & $\mathrm{O}$ & $\mathrm{O}$ & $\mathrm{O}$ & Krinner et al. (2005) \\
\hline 8 & SiB3-JPL & $\mathrm{O}$ & $\mathrm{O}$ & $\mathrm{O}$ & Baker et al. (2008) \\
\hline 9 & SiB3CASA & $\mathrm{O}$ & $\mathrm{O}$ & $\mathrm{O}$ & Schaefer et al. (2008) \\
\hline 10 & TEM6 & $\mathrm{O}$ & $\mathrm{O}$ & $\mathrm{O}$ & Hayes et al. (2011) \\
\hline 11 & VEGAS2.1 & $\mathrm{O}$ & $\mathrm{O}$ & $\mathrm{O}$ & Zeng et al. (2005) \\
\hline 12 & VISIT & $\mathrm{O}$ & $\mathrm{O}$ & $\mathrm{O}$ & Ito and Inatomi (2012) \\
\hline
\end{tabular}

94 CLM4, Community Land Model version 4; CLM4VIC, CLM4 with Variable Infiltration Capacity

95 Runoff Parameterization; DLEM, Dynamic Land Ecosystem Model; GTEC, Global Terrestrial

96 Ecosystem Carbon model; ISAM, Integrated Science Assessment Model; LPJ-wsl, Lund-Potsdam-

97 Jena Dynamic Global Vegetation Model, Swiss Federal Research Institute WSL modification;

98 ORCHIDEE-LSCE, Organizing Carbon and Hydrology in Dynamic Ecosystems; SiB3-JPL: Simple

99 Biosphere version 3 by Jet Propulsion Laboratory; SiBCASA, SiB3 with Carnegie-Ames-Stanford

100 Approach; TEM6: Terrestrial Ecosystem Model version 6; VEGAS2.1, Vegetation Global

101 Atmosphere and Soil version 2.1; VISIT, Vegetation Integrative SImulator for Trace gases. 


\section{Figures}

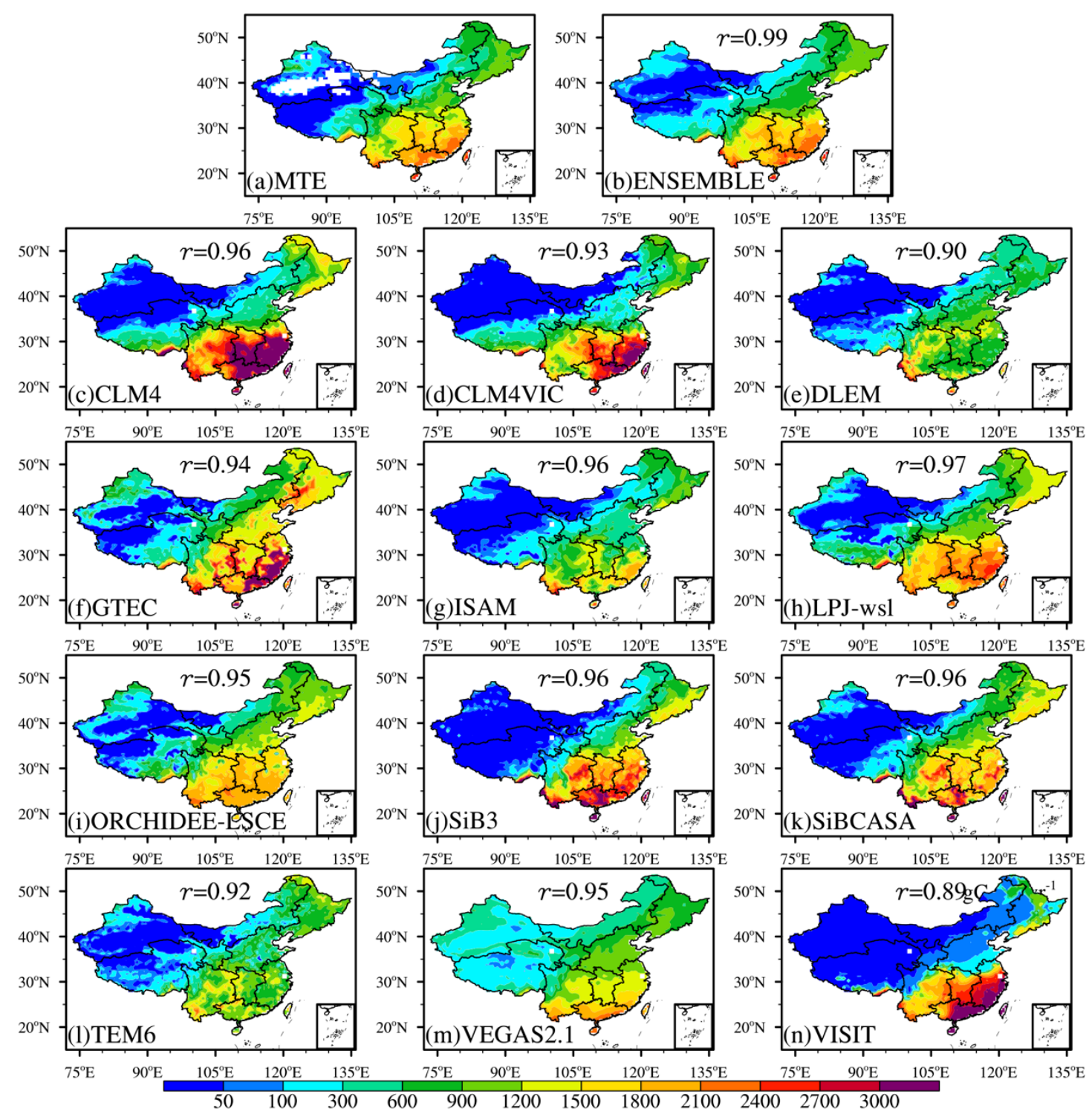

5 Figure S1. Annual terrestrial ecosystem gross primary production (GPP) from the MTE (1982-2010) and MsTMIP models (1981-2010 from SG3 simulation) over China. $r$ is the spatial correlation coefficient with the MTE, and ENSEMBLE is the ensemble mean of the twelve MsTMIP models. 


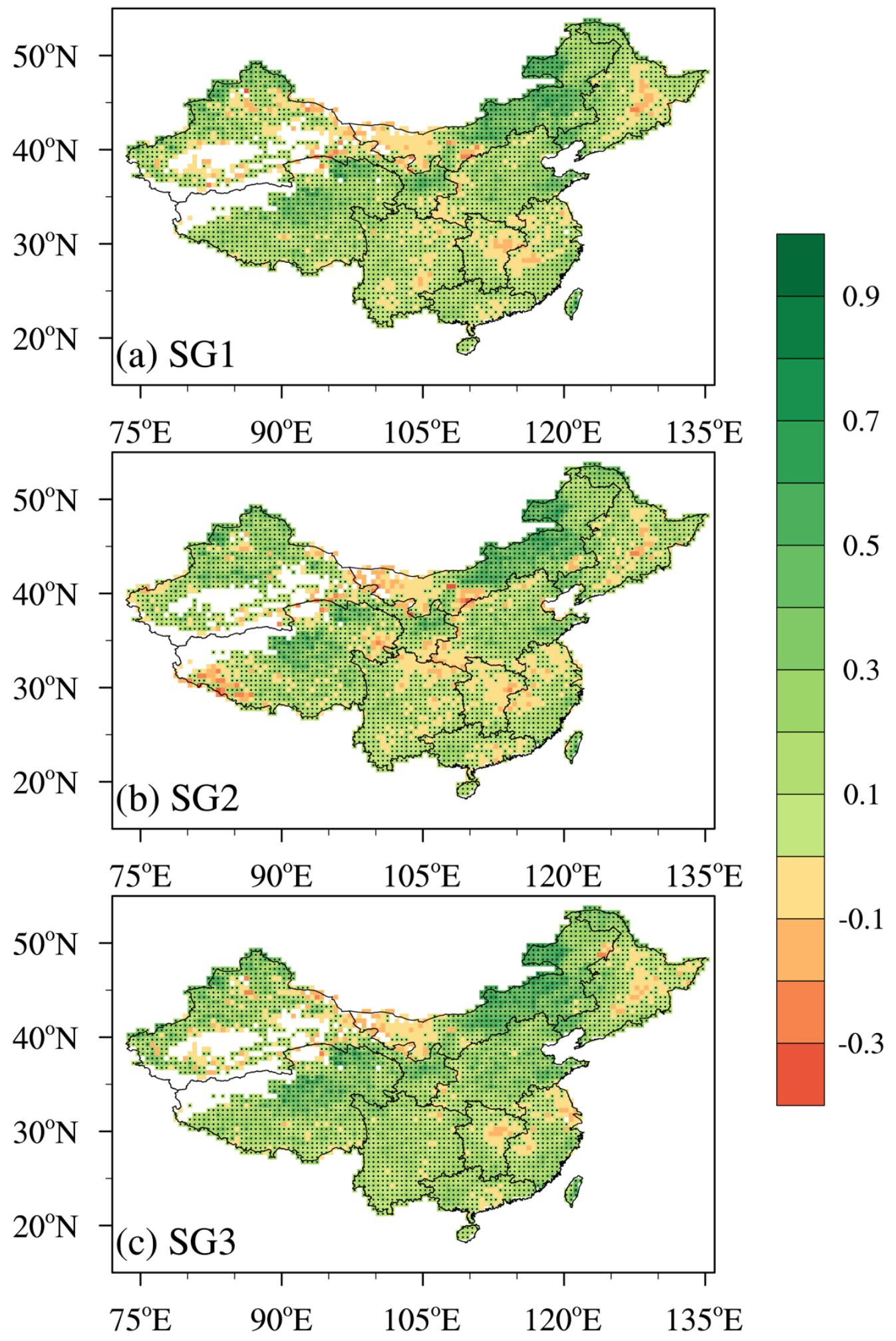

Figure S2. Spatial patterns of temporal correlation coefficients between annual GPP (1982-2010) from MTE and that from ensemble mean of MsTMIP simulations, including : (a) SG1, (b) SG2, and (c) SG3. Stippling highlights regions with significant correlations $(\mathrm{p}<0.05)$. 

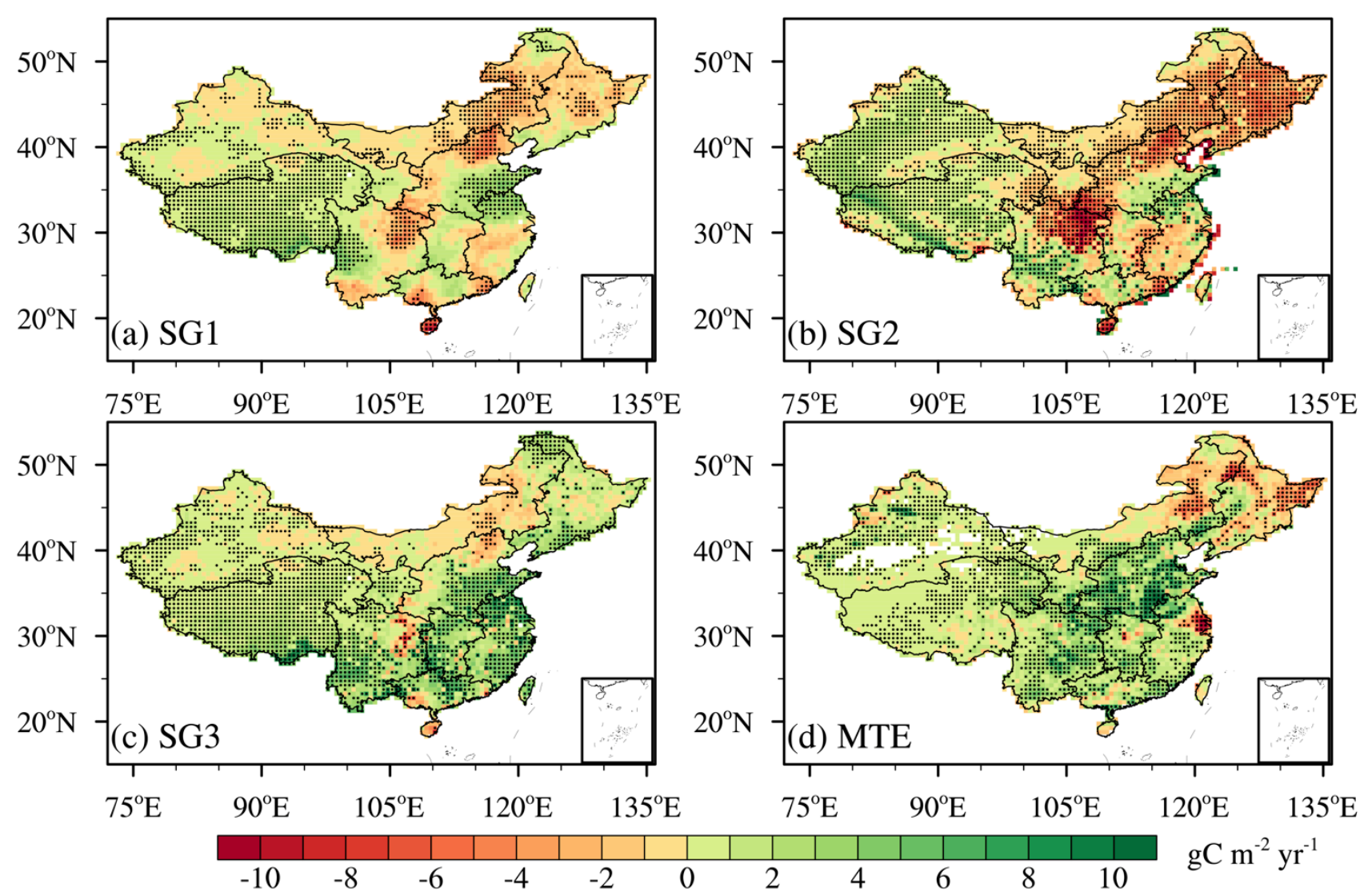

Figure S3. Trends in annual GPP (1982-2010) from the ensemble mean of MsTMIP simulations: (a) SG1, (b) SG2, (c) SG3 and (d) MTE. Stippling highlights regions with significant trend ( $<0.05$ ). 


\section{References}

Ahlström, A., Raupach, M., Schurgers, G., Smith, B., Arneth, A., Jung, M., Reichstein, M., Canadell, J., Friedlingstein, P., Jain, A., Kato, E., Poulter, B., Sitch, S., Stocker, B., Viovy, N., Wang, Y., Wiltshire, A., Zaehle, S., and Zeng, N.: The dominant role of semi-arid ecosystems in the trend and 5 variability of the land $\mathrm{CO}_{2}$ sink, Science, 348(6237), 895-899, 2015.

Baker, I. T., Prihodko, L., Denning, A. S., Goulden, M., Miller, S. and da Rocha, H. R.: Seasonal drought stress in the Amazon: reconciling models and observations, J. Geophys. Res., 113, G00B01, doi: 10.1029/2007JG000644, 2008.

Chen, M., Rafique, R., Asrar, G. R., Bond-Lamberty, B., Ciais, P., Zhao, F., Reyer, C. P. O., Ostberg,

10 S., Chang, J., Ito, A., Yang, J., Zeng, N., Kalnay, E., West, T., Leng, G., Francois, L., Munhoven, G., Henrot, A., Tian, H., Pan, S., Nishina, K., Viovy, N., Morfopoulos, C., Betts, R., Schaphoff, S., Steinkamp, J., and Hickler, T.: Regional contribution to variability and trends of global gross primary productivity, Environ. Res. Lett., 12, 105005, 2017.

Hayes, D. J., McGuire, A. D., Kicklighter, D. W., Gurney, K. R., Burnside, T. J. and Melillo, J. M.: Is

15 the northern high-latitude land-based $\mathrm{CO}_{2}$ sink weakening? Global Biogeochem. Cycles, 25, GB3018, doi: 10.1029/2010GB003813, 2011.

Huntzinger, D. N., Schwalm, C., Michalak, A. M., Schaefer, K., King, A. W., Wei, Y., Jacobson, A., Liu, S., Cook, R. B., Post, W. M., Berthier, G., Hayes, D., Huang, M., Ito, A., Lei, H., Lu., C., Mao., J., Peng, C. H., Peng, S., Poulter, B., Ricciuto, D., Shi, X., Tian, H., Wang, W., Zeng, N., Zhao, F., 20 and Zhu, Q.: The North American Carbon Program Multi-scale Synthesis and Terrestrial Model Intercomparison Project: Part 1: overview and experimental design, Geosci. Model Dev. 6, 2121-2133, 2013.

Hurtt, G. C., Chini, L., Frolking, S., Betts, R., Edmonds, J., Feddema, J., Fisher, G., Goldewijk, K. K., Hibbard, K., Houghton, R., Janetos, A., Jones, C., Kinderman, G., Konoshita, T., Riahi, K.,

25 Shevliakova, E., Smith, S. J., Stefest, E., Thomson, A. M., Thornton, P., van Vuuren, D., and Wang, Y.: Harmonization of land-use scenarios for the period 1500-2100: 600 years of global gridded annual land-use transitions, wood harvest, and resulting secondary lands, Clim. Change, 109, 117-161, doi:10.1007/s10584-011-0153-2, 2011.

Ito, A., and Inatomi, M.: Water-use efficiency of the terrestrial biosphere: A model analysis focusing

30 on interactions between the global carbon and water cycles, J. Hydrometeorol., 13(2), 681-694, 2012. Jain, A. K., Meiyappan, P., Song, Y., and House, J.: $\mathrm{CO}_{2}$ emissions from land-use change affected more by nitrogen cycle, than by the choice of land-cover data, Global Change Biol., 19, 2893-2906, doi: $10.1111 / \mathrm{gcb} .12207,2013$. 
Jung, M., Henkel, K., Herold, M., and Churkina, G.: Exploiting synergies of global land cover products for carbon cycle modeling, Remote Sens. Environ., 101, 534-553, doi:10.1016/j.rse.2006.01.020, 2006.

Krinner, G., Viovy, N., de Noblet-Ducoudré , N., Ogée, J., Polcher, J., Friedlingstein, P., Ciais, P.,

5 Sitch, S., and Prentice, I. C.: A dynamic global vegetation model for studies of the coupled atmospherebiosphere system, Global Biogeochem. Cycles, 19, GB1015, doi: 10.1029/2003GB002199, 2005.

Lei, H., Huang, M., Leung, L. R., Yang, D., Shi, X. Mao, J., Hayes, D. H., Schwalm, C. R., Wei, Y., and Liu, S.: Sensitivity of global terrestrial gross primary production to hydrologic states simulated by the community land model using two runoff parameterizations, J. Adv. Model Earth Syst., 6, 658-679,

102014.

Mao, J., Thornton, P. E., Shi, X., Zhao, M. and Post, W. M.: Remote sensing evaluation of CLM4 GPP for the period 2000-09, J. Clim., 25, 5327-5342, doi:10.1175/JCLI-D-11-00401.1, 2012.

Piao, S., Fang, J., Ciais, P., Peylin, P., Huang, Y., Sitch, S., and Wang, T.: The carbon balance of terrestrial ecosystems in China, Nature, 458, 1009-1013, 2009.

15 Ricciuto, D. M., King, A. W., Dragoni, D. and Post, W. M.: Parameter and prediction uncertainty in an optimized terrestrial carbon cycle model: effects of constraining variables and data record length, J. Geophys. Res., 116, G01033. doi: 10.1029/2010JG001400, 2011.

Schaefer, K., Collatz, G. J., Tans, P., Denning, A. S., Baker, I., Berry, J., Prihodko, L., Suits, N., and Philpott, A.: Combined Simple Biosphere/Carnegie-Ames-Stanford Approach terrestrial carbon cycle 20 model, J. Geophys. Res., 113, G03034, doi: 10.1029/2007JG000603, 2008.

Sen, P. K.: Estimates of the regression coefficient based on Kendall's tau, J. Amer. Stat. Assoc., 63, 1379-1389, 1968.

Shi, X., Mao, J., Thornton, P. E., Hoffman, F. M. and Post, W. M.: The impact of climate, $\mathrm{CO}_{2}$, nitrogen deposition and land use change on simulated contemporary global river flow, Geophys. Res.

25 Lett., 38, L08704. doi: 10.1029/2011GL046773, 2011.

Sitch, S., Smith, B., Prentice, I. C., Arneth, A., Bondeau, A., Cramer, W., Kaplans, J. O., Levis, S., Lucht, W., Sykes, M. T., Thonicke, K., and Venevsky, S.: Evaluation of ecosystem dynamics, plant geography and terrestrial carbon cycling in the LPJ dynamic global vegetation model, Global Change Biol., 9, 161-185, 2003.

30 Tian, H., Chen, G., Zhang, C., Liu, M., Sun, G., Chappelka, A., Ren, W., Xu, X., Lu, C., Pan, S., Chen, H., Hui, D., McNulty, S., Lockaby, G., and Vance, E.: Century-scale responses of ecosystem carbon storage and flux to multiple environmental changes in the southern United States, Ecosystems, 15, 674-694, 2012. 
Tian, H., Xu, X., Lu, C., Liu, M., Ren, W., Chen, G., Melillo, J., and Liu, J.: Net exchanges of $\mathrm{CO}_{2}$, $\mathrm{CH}_{4}$, and $\mathrm{N}_{2} \mathrm{O}$ between China's terrestrial ecosystems and the atmosphere and their contributions to global climate warming, J. Geophys. Res. 116, G02011, doi: 10.1029/2010JG001393, 2011.

Wei, Y., Liu, S., Huntzinger, D. N., Michalak, A. M., Viovy, N., Post, W. M., Schwalm, C. R., 5 Schaefer, K., Jacobson, A., Lu., C., Tian, H., Ricciuto, D., Cook, R. B., Mao., J., and Shi, X.: The North American Carbon Program Multi-scale Synthesis and Terrestrial Model Intercomparison Project-Part 2: Environmental driver data, Geosci. Model Dev. 7, 2875-2893, 2014a.

Wei, Y., Liu, S., Huntzinger, D. N., Michalak, A. M., Viovy, N., Post, W. M., Schwalm, C. R., Schaefer, K., Jacobson, A. R., Lu, C., Tian, H., Ricciuto, D.M., Cook, R.B., Mao, J., and Shi, X.:

10 NACP MsTMIP: Global and North American Driver Data for Multi-Model Intercomparison, ORNL DAAC, Oak Ridge, Tennessee, USA. https://doi.org/10.3334/ORNLDAAC/1220, 2014b.

Zeng, N., Mariotti, A. and Wetzel, P.: Terrestrial mechanisms of interannual $\mathrm{CO}_{2}$ variability, Global Biogeochem. Cycles, 19, GB1016, doi: 10.1029/2004GB002273, 2005. 